\title{
Perancangan Sistem Informasi Persediaan Barang Menggunakan Visual Basic 2010 (Vb.Net) Pada PT. Solusi Rekatama Makmur
}

\author{
Sri Rejeki $1^{1,}$, Ismasari Nawangsih ${ }^{2}$, Siti Setiawati ${ }^{1}$ \\ ${ }_{1}^{1}$ Program Studi: Teknik Informatika; Institusi; Alamat,Jln raya Perjuangan Bekasi \\ Universitas Bhayangkara Jakarta Raya e-mail: sri.rejeki@dsn.ubharajaya.ac.id \\ ${ }^{2}$ Program Studi: Teknik Informatika; Institusi; Alamat: Jl.Inpeksi Kalimalang, telp/fax \\ dari Institusi:Universitas Pelita Bangsa; e-mail: ismasari.n@pelitabangsa.ac.id
}

* Korespondensi: e-mail: sri.rejeki@dsn.ubharajaya.ac.id

\begin{abstract}
The warehousing management system is a key in the supply chain, where the main objective is to control all the processes that take place such as shipping and receiving. Currently the update of inventory data in PT. The Rekatama Makmur solution is periodically not updated every time a transaction occurs and is performed by a single computer performed by a warehouse officer, so that the other part of the employee is constrained in getting the latest data needed to make a business decision. Problems in this research how to make inventory information system for PT. Rekatama Makmur solution that produces updated inventory information every transaction and can generate information for warehouse officer, purchasing, and sales department. This research uses design and development which is done using VB.Net and MySql programming language as database management system.
\end{abstract}

Keywords: Inventory, Information, System, VB.Net, MySQL.

\begin{abstract}
Abstrak
Sistem manajemen pergudangan merupakan kunci utama dalam rantai pasok (supply chain), dimana yang menjadi tujuan utama adalah mengontrol segala proses yang terjadi didalamnya seperti pengiriman (shipping) dan penerimaan (receiving). Saat ini pembaruan data persediaan barang di PT. Solusi Rekatama Makmur dilakukan secara periodik tidak diperbarui setiap terjadi transaksi dan dilakukan oleh satu komputer saja yang dilakukan oleh petugas gudang (warehouse officer), sehingga karyawan bagian lain mengalami kendala dalam mendapatkan informasi data terbaru yang dibutuhkan untuk melakukan keputusan bisnis. Permasalahan dalam penelitian ini bagaimana membuat sistem informasi persediaan barang untuk PT. Solusi Rekatama Makmur yang menghasilkan informasi persediaan barang yang diperbarui setiap terjadi transaksi serta dapat menghasilkan informasi bagi petugas gudang (warehouse officer), bagian pembelian (purchasing), dan bagian penjualan (sales admin). Penelitian ini menggunakan perancangan dan pengembangan yang dilakukan menggunakan bahasa pemrograman VB.Net dan MySql sebagai sistem manajemen basis data.
\end{abstract}

Kata kunci: Sistem, Informasi, Persediaan Barang, VB.Net, MySQL. 


\section{Pendahuluan}

PT. Solusi Rekatama Makmur yang berlokasi di kawasan industri MM2100, Bekasi merupakan perusahaan yang bergerak di bidang penjualan peralatan dan perlengkapan pengecatan (painting equipment) untuk kebutuhan perusahaan pabrikan (manufacturing company) di Indonesia, kegiatan utamanya adalah menjual peralatan dan perlengkapan pengecatan beserta suku cadangnya, perusahaan ini berdiri sejak tahun 2002 dan mengalami perkembangan bisnis yang sangat baik karena menjadi distributor resmi (authorized distributor) beberapa produsen peralatan pengecatan, salah satunya adalah GRACO.INC yang berasal dari Amerika dengan merk dagang GRACO. Selain penjualan, PT. Solusi Rekatama Makmur juga di dukung dengan layanan teknis (technical service), desain dan pemasangan (installation) yang bertujuan untuk mengembangkan bisnis perusahaan dan memenuhi permintaan pasar.

Sistem manajemen pergudangan merupakan kunci utama dalam rantai pasok (supply chain), dimana yang menjadi tujuan utama adalah mengontrol segala proses yang terjadi didalamnya seperti pengiriman (shipping) dan penerimaan (receiving).

Gudang dan pergudangan penting bagi perusahaan karena dapat mempengaruhi pendapatan perusahaan. Saat ini, dalam pembaruan data persediaan barang di PT. Solusi Rekatama Makmur dilakukan secara periodik tidak diperbarui setiap terjadi transaksi dan dilakukan oleh satu komputer saja dan direkap dalam format excel yang dilakukan oleh petugas gudang (warehouse officer) tanpa ada basis data (database) yang tersistem dengan baik, salah satu pengolahan data pergudangan adalah pengolahan data persediaan barang dalam penanganan alur transaksi barang masuk dan barang keluar yang dilakukan oleh petugas gudang yang menghasilkan informasi persediaan barang hanya untuk petugas gudang, sedangkan kebutuhan perusahaan yang juga semakin meningkat yaitu membutuhkan informasi yang dapat diakses bagian lain yaitu bagian penjualan (sales admin) yang membutuhkan informasi persediaan barang di saat membuat penawaran harga untuk menentukan waktu pengiriman. Pihak lain yang membutuhkan informasi persedian barang adalah bagian pembelian (purchasing) yang menggunakan informasi tersebut untuk mengambil keputusan dalam proses pembelian barang.

Oleh karena itu, diperlukan suatu konsep pengolahan data pergudang secara terkomputerisasi lengkap dengan berbagai fitur agenda dan laporan yang disediakan sesuai dengan kebutuhan pihak manajemen sehingga berbagai kesulitan yang berhubungan dengan pengolahan data barang dapat diatasi, maka proses pengolahan data barang dapat berjalan lebih efektif dan efisien.

Berdasarkan uraian tersebut, maka penulis tertarik untuk merancang sistem informasi persediaan barang yang dapat memberikan informasi yang tepat dan akurat dengan VB.Net untuk bahasa pemrograman dan MYSQL sebagai basis datanya untuk dapat memberi solusi bagaimana sistem informasi dapat dikelola dengan baik. Oleh karena itu sesuai dengan 
permasalahan dan kebutuhan terhadap pengolahan data persediaan barang inilah peneliti mengambil judul: "Analisa Perancangan Sistem Informasi Persediaan Barang Menggunakan VB.Net Pada PT. Solusi Rekatama Makmur.

Permasalahan yang terdapat pada proses penyajian informasi persediaan barang pada PT. Solusi Rekatama Makmur dinilai belum optimal, antara lain:

1. Informasi persediaan barang hanya bisa diakses oleh petugas gudang padahal informasi tersebut juga diperlukan oleh bagaian sales dan bagian pembelian untuk digunakan dalam proses pengambilan keputusan bisnis.

2. Belum adanya sistem informasi untuk mengelola data pengiriman (shipping) dan penerimaan (receiving) sehingga sering terjadi kesalahan informasi kedatangan dan pengiriman barang.

3. Belum adanya suatu sistem informasi untuk mengolah data persediaan barang yang secara otomatis diperbaharui setiap terjadi transaksi sehingga sering terjadi kesalahan informasi jumlah data barang yang diperbaharui oleh bagian gudang dengan aktual data yang ada.

Sistem adalah sekumpulan objek-objek yang saling berelasi dan berinteraksi serta hubungan antar objek bisa dilihat sebagai satu kesatuan yang dirancang untuk mencapai suatu tujuan . Menurut Hanif Al Fatta (2007:3)

Sistem informasi adalah suatu sistem di dalam suatu organisasi yang mempertemukan kebutuhan pengolahan transaksi harian yang mendukung fungsi operasi organisasi yang bersifat manajerial dengan kegiatan strategi dari suatu organisasi untuk dapat menyediakan kepada pihak luar tertentu dengan laporan -laporan yang diperlukan, Tata Sutabri (2005: 42).

Menurut Holy dan Martinus (2005:1) persediaan (inventory) adalah item atau material yang dipakai oleh suatu organisasi atau perusahaan untuk menjalankan bisnisnya. Jika perusahaan tersebut memproduksi suatu barang atau jasa maka material tersebut digunakan untuk mendukung atau menyediakan kebutuhan produksi.

SDLC atau Software Development Life Cycle atau sering disebut juga System Development Life Cycle adalah proses mengembangkan atau mengubah suatu sistem perangkat lunak dengan menggunakan model-model dan metodologi yang digunakan orang untuk mengembangkan sistem-sistem perangkat lunak sebelumnya (berdasarkan best practice atau cara-cara yang sudah teruji baik), Rosa A.S dan M. Shalahuddin (2015:25).

MYSQL merupakan software sistem manajemen database (Database Management System/DBMS) yang sangat popular dikalangan pemrogram. Kepopuleran MYSQL dimungkinkan karena kemudahannya untuk digunakan, cepat secara kinerja query dan 
mencukupi untuk kebutuhan database perusahaan-perusahaan skala menengah kecil. Software database MYSQL kini dilepas sebagai software manajemen database yang open source, sebelumnya merupakan software database yang shareware. Database MYSQL tersedia secara bebas cuma-cuma dan boleh digunakan oleh setiap orang, dengan lisensi open source GNU General Public License (GPL) ataupun lisensi komersil non-GPL.

Microsoft Visual Basic .NET adalah sebuah alat untuk mengembangkan dan membangun aplikasi yang bergerak di atas sistem .NET Framework, dengan menggunakan bahasa Basic. Dengan menggunakan alat ini, para programmer dapat membangun aplikasi Windows Forms, Aplikasi web berbasis ASP .NET, dan juga aplikasi

\section{Metode Penelitian}

\subsection{Observasi}

Observasi dilakukan dengan melakukan pengamatan atau peninjauan langsung di PT. Solusi Rekatama Makmur yang berada di Jl. Selayar Kawasan Industri MM2100, Cibitung, Bekasi .

\subsection{Studi Pustaka dan Literatur}

Pengumpulan data yang bersumber dari berbagai buku yang menjadi referensi, pedoman penulisan riset, penelitian, skripsi atau diktat yang menunjang pemecahan permasalahan yang tidak didapatkan dalam penelitian.

Studi literatur bertujuan untuk mempelajari teori-teori dan penelitian yang berhubungan dengan sistem informasi yang akan dibuat sehingga diperoleh hasil berbeda dan lebih baik.

\subsection{Kuisioner}

Dalam metode ini penulis memberikan sebuah tanya jawab seputar program yang dibuat dan sekaligus memberikan nilai terhadap hasil uji coba program tersebut.

\subsection{Sistem Yang Berjalan}

Informasi persedian barang pada PT. Solusi Rekatama Makmur dihasilkan dari proses pengiriman (shipping) dan penerimaan (receiving). Sistem yang berjalan saat ini digambarkan dengan flowmap diagram yang dilakukan berdasarkan tahapan sebagai berikut.

1. Pengiriman barang (shipping)

Berikut tahapan prosedur pengiriman barang: 
a. Bagian penjualan (sales admin) memeriksa ketersediaan barang yang yang akan dikirim kepada customer dan apabila barang tersedia sales admin membuat form permintaan barang kepada bagian gudang (warehouse officer).

b. Warehouse officer menerima form permintaan barang kemudian melakukan pengambilan barang untuk disiapkan pada lokasi pengiriman dan membubuhkan tanda tangan pada form permintaan barang sebagai pemberitahuan bahwa barang sudah diambil dan siap dikirim, kemudian warehouse officer memperbaharui data persediaan barang dalam format excel. Data persediaan barang yang diolah oleh warehouse officer diberikan kepada sales admin setiap akhir shift.

c. Form permintaan barang yang sudah ditanda tangan oleh warehouse officer kemudian di buatkan surat jalannya (delivery order).

2. Penerimaan barang (receiving)

Berikut tahapan prosedur penerimaan barang:

a. Bagain pembelian (purchasing manager) mendapatkan permintaan pembelian (purchase request) dari bagian penjualan (sales admin). Sebelum membuat dokumen pembelian (purchase order) purchasing manager harus memeriksa informasi ketersediaan barang yang diminta dalam purchase request. Kemudian purchasing manager mengambil keputusan pembuatan purchase order dan mengirim purchase order kepada supplier.

b. Supplier mengirim barang yang telah di beli oleh purchasing manager dengan menyertakan purchase order dan surat jalan atas barang yang dikirim. Warehouse officer menerima fisik barang, dokumen purchase order dan surat jalan. Setelah fisik barang dan dokumen sesuai warehouse officer melakukan validasi pada surat jalan dengan cara dicap dan tanda tangan kemudian dokumen yang sudah divalidasi di serahkan kepada purchasing manager.

c. Warehouse officer memperbaharui data persediaan barang dalam format excel. Data persediaan barang yang diolah oleh warehouse officer diberikan kepada purchasing manager setiap akhir shift. 
Berdasarkan proses pengiriman dan penerimaan barang pada sistem yang sedang berjalan dapat diketahui actor dan flowmap yang ada dalam proses tersebut, yaitu:

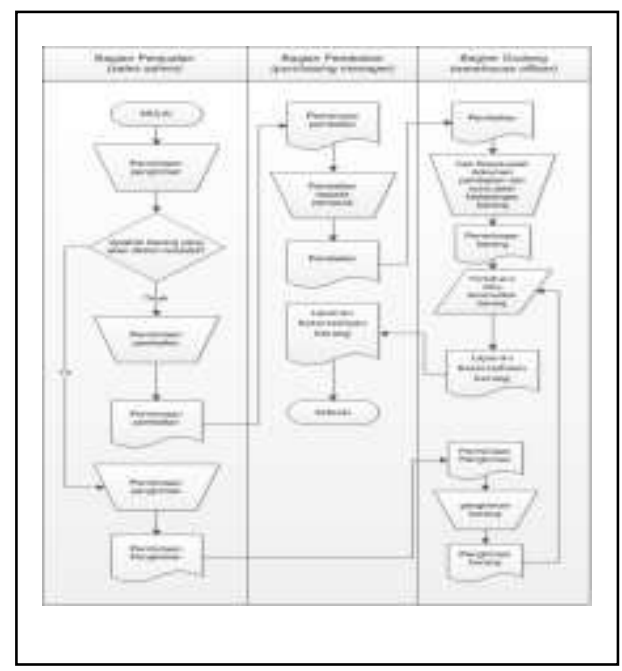

Sumber : Hasil Penelitian (2021)

Gambar 1..Flowmap diagram sistem informasi persediaan barang yang berjalan

\subsection{Konsep Perancangan Sistem}

Rancangan sistem yang akan dibuat untuk PT. Solusi Rekatama Makmur ini dibutuhkan metode agar dapat menuangkan ide awal sesuai dengan yang diharapkan dalam implementasinya. Untuk itu metode yang tepat dalam pengembangan sistem ini adalah menggunakan metode SDLC (System Development Life Cycle) dengan model waterfall yang diterapkan dalam suatu basis sistem informasi komputerisasi, tahapan pengembangan ini bisa diuraikan di halaman berikutnya :

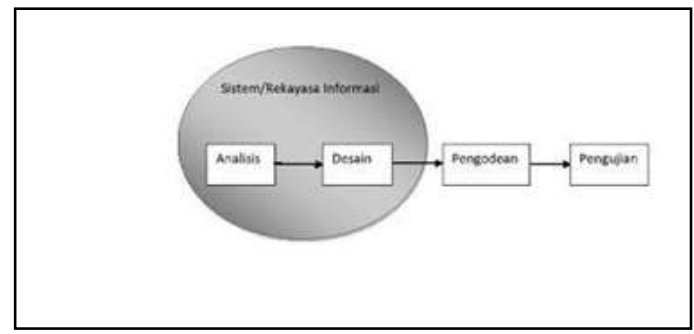

Sumber : Rosa A.S dan M. Shalahuddin (2015)

Gambar 2. Ilustrasi Model Waterfall 


\section{Hasil dan Pembahasan}

\subsection{Usulan Sistem Yang Berjalan}

Sistem yang diusulkan berupa sistem yang berbasis aplikasi program yang dikhususkan untuk PT. Solusi Rekatama Makmuur yaitu dirancang dengan menggunakan bahasa pemrograman VB.Net dan database menggunakan MySQL yang sudah menjadi paket dengan server.

\subsection{Tahap Perancangan Sistem}

Tahap perancangan sistem adalah tahap pembangunan sebuah sistem informasi persedian barang di PT.Solusi Rekatama yang telah direncanakan. Dalam membuat rancangan proses pada sistem informasi persediaan barang ini peneliti menggunakan Flowmap sebagai alat dalam merancang proses yang akan terjadi di dalam aplikasi. Pada tahap ini penulis menjelaskan alur yang akan dibuat untuk sistem yang akan diterapkan dalam proses Pengiriman dan penerimaan barang. Perancangan sistem yang akan dibuat dapat di jelaskan menggunakan beberapa gambaran proses sebagai berikut :

\subsubsection{Flowmap Sistem Usulan}

Narasi Prosedur Manual

1. Narasi pengiriman Barang

a. Proses pengiriman barang dimulai ketika bagian penjualan yang menerima dokumen pembelian dari customer kemudian pembelian tersebut di cek ketersediaan nya. Apabila barang yang dibeli oleh customer tersedia bagian penjualan akan membuat permintaan pengiriman.

b. Permintaan pengiriman yang diminta oleh bagian penjualan akan menjadi data pengiriman pending bagi bagian gudang. Data batang yang tercantum pada data pengiriman pending di siapkan pengirimannya oleh bagian gudang kemudian status pengirimannnya di rubah menjadi closed.

c. Kemudian Bagian gudang mencetak surat jalan rangkap tiga, surat jalan tersebut harus di tandatangani division manager, lembar pertama dan kedua untuk dokumen pengiriman sedangkan lembar ketiga untuk diarsip bagian gudang.

2. Narasi Penerimaan Barang 
a. Penerimaan barang dimulai ketika supplier mengirim barang yang disertakan surat jalan pengiriman dan dokumen pembelian dari bagian pembelian kepasa supplier, kemudian bagian gudang menerima kedatangan barang tersebut dan mengecek kesesuaian jumlah antara fisik dan dokumen

b. Apabila fisik dan dokumen sudah sesuai kemudian bagian gudang mebuat transaksi penerimaan barang. Transaksi yang telah berhasil di buat akan menjadi laporan bagi bagian pembelian dan akan di cetak dua rangkap, satu lembar utuk di arsip dan satu lembar untuk bagian penjualan.Berikut flowmap untuk proses penerimaan dan pengiriman barang

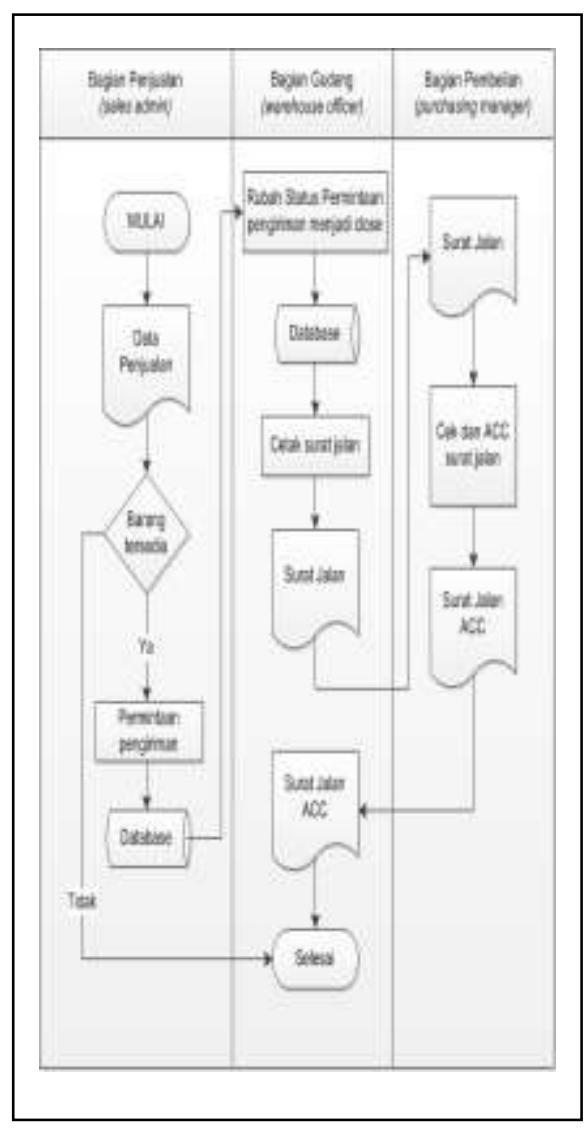

Sumber : Hasil Penelitian (2021)

Gambar 3. Flowmap pengiriman barang 


\subsubsection{Diagram Konteks Sistem Informasi Persediaan Barang}

Diagram konteks menggambarkan hubungan antara entitas bagian persediaan barang (bagian gudang), bagian pembelian (purchasing), dan bagian penjualan (sales admin) dengan sistem informasi persediaan barang.

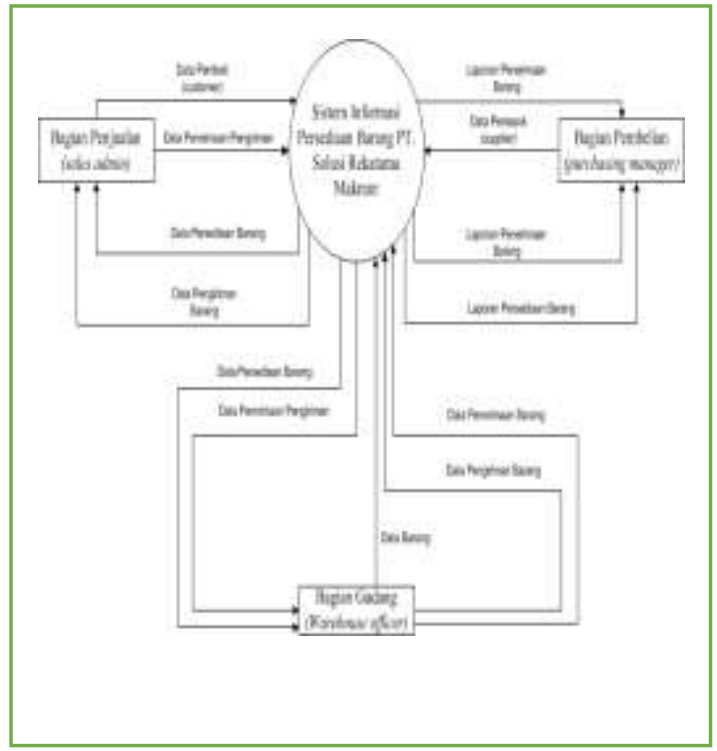

Sumber : Hasil Penelitian (2021)

Gambar 5. Diagram Konteks Sistem Informasi Persediaan Barang 


\subsubsection{HIPO (Hierarchy Input Proses Output)}

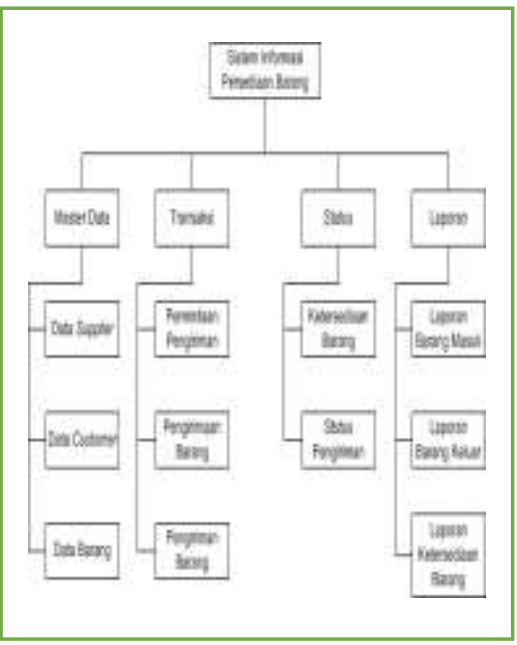

Sumber : Hasil Penelitian (2021)

Gambar 6.HIPO (Hierarchy Input Proses Output)

\subsubsection{Aplikasi Sistem Informasi Persediaan Barang Halaman Utama}

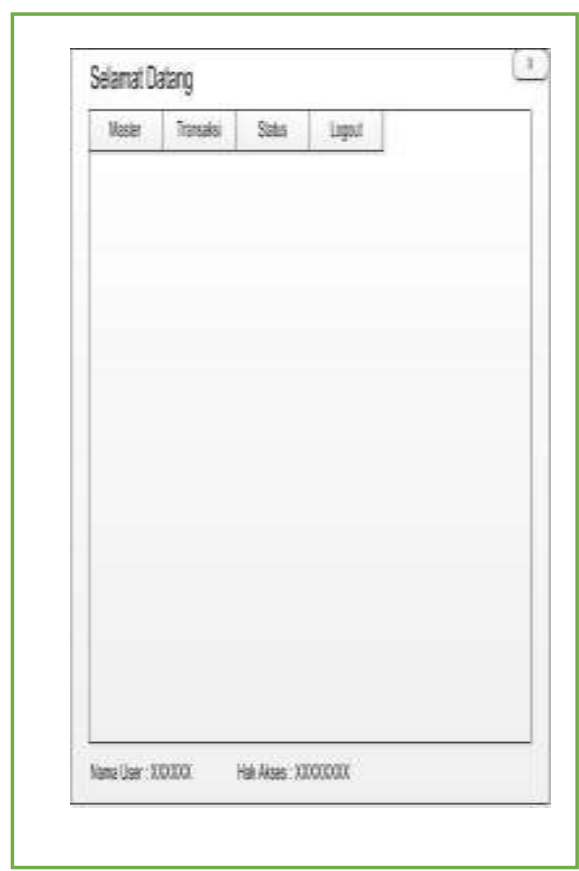

Sumber : Hasil Penelitian (2021)

Gambar 7. Halaman Utama Perancanngan Sistem Informasi Persedian Barang 


\subsection{Hasil Penelitian Perancangan Sistem Informasi Persediaan Barang.}

1. Sistem dapat berfungsi dengan baik.

2. Sistem yang dibuat sesuai dengan perancangan Sistem Informasi Persediaan Barang.

3. Sistem dapat mengatasi permasalahan persediaan barang dengan cepat.

4. Aplikasi program berjalan sesuai dengan kebutuhan.

\section{Kesimpulan}

Berdasarkan hasil penelitian dan observasi serta pembahasan yang dilakukan penulis pada Sistem Informasi Persediaan Barang, maka penulis dapat menarik kesimpulan sebagai berikut:

1. Dengan sistem informasi persediaan barang ini menghilangkan potensi transaksi pengiriman dan pengeluaran barang yang tidak tercatat dalam data persediaan barang, sehingga menghasilkan data yang akurat.

2. Data yang akurat dalam penyajian informasi persediaan barang berguna bagi bagian penjualan menentukan waktu pengiriman.

3. Dengan sistem informasi persediaan barang yang dibuat dapat memberikan informasi persediaan barang secara real time bagi bagian pembelian dimana informasi tersebut dapat dijadikan acuan dalam melakukan keputusan pembelian barang.

4. Pada sistem informasi ini mampu memberikan informasi tentang master barang, transaksi dan laporan berdasarkan periode tertentu agar memudahkan dalam pengambilan keputusab berkaitan dengan ketersediaan barang.

\section{Daftar Pustaka}

Al Fatta, Hanif. 2007. Analisis dan Perancangan Sistem Informasi untukKeunggulan Bersaing Perusahaan dan Organisasi Modern. Yogyakarta; Andi Offset.

Abdul Kadir dan Terra CH. Triwahyuni, 2012. Pengenalan Teknologi Informasi. Yogyakarta ;Andi.

Hole Icun Yuniarto dan Martinus Getty Santika, 2005. Business Concepth Implementation Series In Inventory Management. Yogyakarta; PT. Elex Media Komputindo.

Huda, Muftakhul dan Bunafit Komputer, 2010. Membuat Aplikasi Database dengan VB .NET 2008 dan MySQL, Jakarta, Elex Media Komputindo.

Jogiyanto, HM, Akt., MBA, Ph.D., 2001. Analisa dan Desain Sistem Informasi: Pendekatan Terstruktur Teori dan Praktek Aplikasi Bisnis, Ed. II, Cet. II Yogyakarta; Andi Publisher.

Jogianto H.M., 2005. Sistem Teknologi Informasi Edisi II Yogyakarta; Andi. 
McLeond, Raymond, Jr, 2001. Sistem Informasi Manajemen Jilid 1 Jakarta, PT. Prenhalindo.

Sutarman. 2009. Pengantar teknologi Informasi. Jakarta: Bumi Aksara.

Sigit Hermawan, 2013. Akuntansi Perusahaan Manufaktur. Yogyakarta : Graha llmu

Tata Sutabri, 2012. Analisis Sistem Informasi, Yogyakarta, Andi. 